\title{
INTEGRASI “RAHMAT” DALAM PEMBELAJARAN MATEMATIKA
}

\author{
I.K.R. Yasa \\ SMA Negeri 1 Kubu \\ Karangasem, Indonesia \\ e-mail: tut ruma@yahoo.com
}

\begin{abstract}
Abstrak
Penelitian ini bertujuan untuk memaparkan peningkatan sikap siswa pada Mata Pelajaran Matematika setelah mengikuti pembelajaran menggunakan sejarah matematika. Jenis penelitian ini adalah penelitian best practise yang dilaksanakan dalam dua tahap, yaitu tahap persiapan dan tahap pelaksanaan. Subjek penelitian ini adalah siswa kelas XII MIA.2 SMAN 1 Kubu Semester 1 Tahun Pelajaran 2019/2020 sebanyak 25 orang yang terdiri dari 10 orang laki-laki dan 15 orang perempuan. Data tentang sikap siswa dikumpulkan melalui kuisioner sikap. Data yang dikumpulkan dianalisis menggunakan analisis deskriptif. Hasil penelitian ini menunjukkan bahwa, sikap siswa kelas XII MIA.2 SMAN 1 Kubu Semester 1 Tahun Pelajaran 2019/2020 terhadap Mata Pelajaran Matematika setelah mengikuti pembelajaran menggunakan sejarah matematika mengalami peningkatan. Sikap siswa mengalami peningkatan dari sebelum pembelajaran dan setelah pembelajaran menggunakan sejarah matematika. Rata-rata sikap siswa sebelum pembelajaran hanya 48,21 pada kategori Cukup, sedangkan setelah pembelajaran rata-rata sikap siswa pada Mata Pelajaran Matematika mengalami peningkatan menjadi 74,00 pada kategori Baik. Sikap siswa yang meningkat berpengaruh positif terhadap peningkatan prestasi belajar matematika. Rata-rata nilai ulangan harian siswa meningkat dari 75,48 dengan ketuntasan belajar $92 \%$ pada ulangan harian 1 menjadi 78,72 dengan ketuntasan $100 \%$ pada ulangan harian 2.
\end{abstract}

Kata kunci: Sejarah Matematika; Sikap Siswa; Pembelajaran Matematika

\begin{abstract}
This research aimed at describing the improvement of the students' attitude towards mathematics lesson after following the lesson using mathematics history. This was a best practice research implemented in two phases: preparation and implementation. The subjects of this research were the students of class XII MIA 2 of SMA N 1 Kubu in the first semester of academic year 2019/2020. There were 25 students consisting of 10 male students and 15 female students. The data of students' attitude were collected through attitude questionnaires. The collected data were then analyzed descriptively. This research showed that the students' attitude of class XII MIA 2 of SMA N 1 Kubu in the first semester of academic year 2019/2020 towards mathematics lesson after following the lesson using mathematics history improved. The students' attitude improved from pre-learning to post-learning using mathematics history. The average of students' attitude was 48.21 before learning and in the fair category, meanwhile after learning, the average of students' attitude towards mathematics lesson improved to 74.00 with good category. The improving students' attitude had positive effect towards the improvement of mathematics learning achievement. The average of students' daily test improved from 75.48 with learning mastery 92\% at the first daily test to 78.72 with learning mastery $100 \%$ at the second daily test.
\end{abstract}

Keywords : History Of Mathematics; Student Attitude; Mathematics Learning 


\section{PENDAHULUAN}

Karakteristik

pembelajaran

matematika yang banyak ditemukan di kelas yaitu fokus pada perhitungan (drill), peran guru lebih dominan (teacher-centered), siswa belum diberikan kesempatan dan didorong untuk menyampaikan pendapat (reasoning), tidak membangun pemahaman konsep, belum berorientasi pemecahan masalah, dan tidak dikaitkan dengan kehidupan sehari-hari. Ketika siswa kelas 5 SD diajarkan perkalian pecahan, sebagian besar guru matematika memulai dengan menjelaskan langsung bagaimana cara mengalikan pecahan yang disertai beberapa contoh sejenis kemudian diakhiri dengan soal latihan. Efek lebih lanjut terkait pembelajaran matematika yang bersifat transmission of knowledge yaitu kurang bermaknanya pembelajaran dan siswa dianggap pintar matematika jika bisa mengerjakan soal sesuai dengan contoh yang dijelaskan. Banyak guru matematika membuat klasifikasi kemampuan matematika siswa di kelas berdasarkan kriteria tersebut. Siswa yang dianggap pintar karena bisa menyelesaikan soal latihan yang lebih menitikberatkan aspek prosedural belum tentu memiliki kemampuan dalam memecahkan masalah matematika yang berkaitan dengan kehidupan sehari-hari.

Efek lebih lanjut terkait pembelajaran matematika yang bersifat transmission of knowledge yaitu kurang bermaknanya pembelajaran dan siswa dianggap pintar matematika jika bisa mengerjakan soal sesuai dengan contoh yang dijelaskan. Pembelajaran matematika yang kurang bermakna membuat siswa merasakan belajar matematika hanya sekedar sekumpulan aturan yang harus dihafal dan dikerjakan. Beberapa pandangan tersebut tentunya melahirkan sikap negatif siswa terhadap pelajaran matematika. Sikap negatif siswa bisa dilihat dari kurangnya minat dan motivasi siswa untuk belajar matematika. Akhirnya, matematika hanyalah momok dalam kelas. Inilah realitas pembelajaran matematika yang tidak bisa dipandang sebelah mata khususnya oleh guru matematika. Salah satu sebab munculnya sikap negatif siswa terhadap pelajaran matematika adalah cara atau strategi guru menyajikan matematika dalam kelas.

Pembelajaran matematika yang lebih mengaktifkan siswa (student-centered), menyenangkan dan bermakna merupakan tuntutan mutlak bagi seorang guru matematika. Hal ini sejalan dengan tuntutan kurikulum baik KTSP atau kurikulum 2013 (K13), bahkan dalam K13 semua pelajaran khususnya matematika harus memuat pendidikan karakter. Pembelajaran harus mampu memberikan nilai-nilai positif bagi siswa sebagai modal dalam pembentukan karakter.

Peraturan Menteri Pendidikan dan Kebudayaan Nomor 21 Tahun 2016 tentang Standar Isi Pendidikan Dasar dan Menengah menyebutkan bahwa salah satu kompetensi Mata Pelajaran Matematika yang harus dimiliki siswa pendidikan menengah adalah memiliki rasa ingin tahu, percaya diri, semangat belajar yang kontinu, pemikiran reflektif, dan ketertarikan pada matematika. Kompetensi tersebut diperlukan agar siswa semangat sebagai pembelajaran sepanjang hayat. Rasa ingin tahu, percaya diri dan semangat belajar yang kontinu akan mendorong siswa untuk terus belajar mengembangkan diri. Pemikiran reflektif, dan ketertarikan pada matematika akan mendorong siswa untuk mempelajari matematika dan memanfaatkan matematika dalam pemecahan masalah kehidupan. Dengan demikian setiap siswa akan berkembang semangat untuk kemampuan memperoleh, mengelola, dan memanfaatkan informasi untuk bertahan hidup pada keadaan yang selalu berubah, tidak pasti, dan kompetitif. Ini menyiratkan bahwa mata pelajaran matematika di SMA sangat penting untuk menyiapkan siswa untuk menjadi anggota masyarakat setelah lulus SMA maupun untuk bekal melanjutkan pendidikan ke perguruan tinggi.

Namun kenyataan yang terjadi di sekolah tidaklah sesuai dengan harapan 
tersebut. Pembelajaran matematika di sekolah masih ada siswa yang beranggapan matematika merupakan pelajaran yang sulit, menakutkan, membosankan, dan tidak menarik. Pelaksanaan pembelajaran matematika sampai saat ini jarang dikaitkan dengan upaya pembentukan sikap, baik terkait dengan sikap sosial maupun sikap terhadap matematika itu sendiri (Parwati, 2013). Keadaan seperti ini akan berdampak pada ketertarikan siswa pada mata pelajaran matematika. Ketertarikan siswa yang rendah akan berdampak pada prestasi belajar matematika siswa. Siswa kelas XII MIA.2 SMA Negeri 1 Kubu juga mengalami hal yang sama. Siswa MIA seharusnya memiliki ketertarikan yang tinggi pada Mata Pelajaran Matematika tetapi ternyata banyak siswa menunjukkan ketertarikan yang rendah pada Mata Pelajaran Matematika. Hal ini tentunya harus dicarikan solusi agar prestasi belajar matematika siswa dapat ditingkatkan.

Menyikapi perubahan paradigma pengajaran menjadi pembelajaran serta menyikapi permasalahan di atas membutuhkan suatu solusi tentang apa yang harus dilakukan agar siswa memiliki ketertarikan dalam belajar matematika. Dengan fokus pengembangkan sifat, watak, dan akhlak, di era digital yang semua pengetahuan tersedia tanpa batas, pendidikan karakter harusnya memang merupakan fokus dari kegiatan pendidikan, termasuk pendidikan matematika (As'ari, 2018). Karena itu, meskipun banyak tantangan yang akan dihadapi, guru matematika harus mampu memanfaatkan pembelajaran matematika untuk pengembangan karakter. Ketertarikan (minat) siswa pada matematika dapat ditumbuhkan dengan mengembangkan persepsi dan sikap positif terhadap Mata Pelajaran Matematika. Guru harus merancang pembelajaran matematika yang mengembangkan sikap positif siswa. Salah satu pembelajaran yang dapat mengembangkan sikap positif siswa terhadap Mata Pelajaran Matematika adalah penggunaan sejarah matematika. Kurnila, dkk (2019) menyatakan bahwa sikap siswa terhadap matematika adalah kecenderungan siswa untuk menerima atau menolak konsep matematika yang diperoleh. Sikap menerima dan menolak konsep matematika cenderung berbeda, sehingga pemahaman terhadap konsep tersebut pun berbeda.

Cabang pengkajian yang dikenal sebagai "Rahmat" (sejarah matematika) adalah penyelidikan terhadap asal mula penemuan di dalam matematika dan sedikit perluasannya, penyelidikan terhadap metode dan notasi matematika pada masa silam. Sebelum zaman modern dan penyebaran ilmu pengetahuan ke seluruh dunia, contoh-contoh tertulis dari pengembangan matematika telah mengalami kemilau hanya di beberapa tempat. Temuan-temuan matematika sejak zaman pra sejarah tentu memberikan pengaruh dan manfaat yang sangat besar. Sejarah matematika diintegrasikan pada setiap pembelajaran matematika. Integrasi sejarah matematika dalam pembelajaran merupakan salah satu alat (history as a tool) atau strategi untuk membangun pembelajaran yang bermakna dan sarat dengan nilai (Wahyu \& Mahfudy, 2016). Dalam proses pembelajaran menggunakan sejarah matematika bukan kita bertindak seperti guru sejarah tetapi sejarah matematika diintegrasikan pada setiap pembelajaran matematika. Sejarah matematika dijadikan sebagai alat penyemangat atau membangun motivasi siswa sebelum belajar. Pembelajaran diawali dengan apersepsi memanfaatkan sejarah hidup tokoh-tokoh matematika yang berjasa dalam pengembangan matematika. Guru melalui sejarah matematika menunjukkan bahwa matematika mempunyai manfaat yang sangat penting sepanjang kehidupan umat manusia. Integrasi sejarah matematika dalam matematika sekolah merupakan sarana yang sangat baik untuk mengenali banyak koneksi yang ada diantara matematika dan pelajaran lain (Furinghetti \& Somaglia, 1998). Integrasi sejarah matematika ke 
dalam pembelajaran memiliki manfaat bagi motivasi siswa yaitu dapat memberikan perspektif baru dan wawasan mengenai matematika (Argaswari, 2018).

Pembelajaran diawali dengan apersepsi memanfaatkan sejarah hidup tokoh-tokoh matematika yang berjasa dalam pengembangan matematika. Guru melalui sejarah matematika menunjukkan bahwa matematika mempunyai manfaat yang sangat penting sepanjang kehidupan umat manusia. Statistik misalnya, sudah digunakan sejak zaman Romawi untuk menyajikan data. Kemampuan siswa membaca data yang ditampilkan dalam bentuk tabel dan diagram sangat dibutuhkan dalam kehidupan. Sejarah matematika ini dapat menumbuhkan pengetahuan siswa mengenai manfaat dan kegunaan matematika. Sejak zaman dahulu, matematika mempunyai peranan yang amat penting. Contohnya materi statistik khususnya penyajian data baik dalam bentuk tabel maupun diagram sangat banyak digunakan dalam berbagai aspek kehidupan. Untuk menggambarkan banyak anggota keluarga, banyaknya binatang peliharaan atau banyaknya hasil panen pada zaman dahulu. Masa kini pun statistik masih banyak digunakan. Pemahaman ini penting diketahui siswa sehingga menumbuhkan sikap positif siswa terhadap pembelajaran matematika. Pada akhirnya sikap positif dan pemahaman pada manfaat matematika dapat meningkatkan minat siswa belajar matematika.

Ada dua hal penting yang harus diperhatikan sebelum menerapkan sejarah matematika, yaitu: apakah penerapan sejarah matematika bisa mengubah persepsi siswa terhadap matematika?; dan apakah penerapan sejarah matematika di kelas bisa membangun dan mengembangkan konsep matematika siswa? Dua pertanyaan ini berkaitan dengan aspek afektif dan kognitif dalam pembelajaran matematika yang juga tuntutan kurikulum baik KTSP maupun K13.

Banyak manfaat yang dapat diambil dari penggunaan sejarah matematika dalam pembelajaran (Sumardyono, 2012). (Fauvel, 2000) menyatakan terdapat tiga dimensi besar pengaruh positif sejarah matematika dalam proses belajar siswa (a) understanding (pemahaman), (b) Enthusiasm (antusiasme), (c) Skills (keterampilan). Lebih lanjut (Fauvel, 2000) menyarankan beberapa cara yang dapat ditempuh dalam menggunakan sejarah dalam pembelajaran matematika di kelas, yaitu: (a) menyebutkan atau menceritakan tentang matematikawan pada zaman dahulu secara menyenangkan, (b) menyediakan pengantar sejarah untuk konsep-konsep yang baru bagi siswa, (c) memacu siswa untuk memahami masalah-masalah sejarah untuk mana konsep-konsep yang telah mereka pelajari merupakan jawabannya, (d) memberitugas-tugas tentang sejarah matematika, (e) melengkapi latihan-latihan di kelas atau di rumah dengan menggunakan tulisantulisan matematika dari zaman dahulu, (f) aktivitas drama langsung dengan kegiatan refleksi interaksi matematika, (g) memacu kreasi tampilan poster atau proyek lain dengan topik-topik sejarah, (h) merencanakan proyek tentang aktivitas lokal matematika pada zaman dahulu, (i) menggunakan contoh-contoh penting dalam sejarah matematika untuk menggambarkan teknik-teknik atau metodemetode matematika, (j) mengeksplorasi miskonsepsi, kesalahan, atau pandangan lain pada zaman dahulu untuk membantu pemahaman dan penyelesaian kembali akan kesulitan-kesulitan yang dijumpai oleh siswa pada masa sekarang, (k) merencanakan suatu pendekatan pedagogik untuk suatu topik tertentu dengan menggunakan perkembangan sejarahnya, (I) merencanakan urutan dan struktur topik dalam silabus pembelajaran dengan landasan sejarah.

Penerapan sejarah matematika dalam pembelajaran merupakan salah satu alat (history as a tool) atau strategi untuk membangun pembelajaran yang bermakna dan sarat dengan nilai pemanfaatan sejarah matematika dalam pembelajaran merupakan suatu inovasi yang 
mengembangkan sikap positif siswa yang lebih baik pada matematika. Selama ini siswa menganggap Mata Pelajaran Matematika hanya mengenai angka dan simbol-simbol yang rumit berbeda dengan ilmu sosial (sejarah). Oleh karena itu, perlu penelitian terkait dengan aspek tersebut. Tujuan yang ingin dicapai melalui penelitian ini adalah meningkatkan sikap siswa kelas XII MIA.2 SMAN 1 Kubu Semester 1 Tahun Pelajaran 2019/2020.

\section{METODE}

Jenis penelitian yang dilakukan adalah penelitian best practice. Penelitian ini dilaksanakan dalam dua tahap kegiatan, yaitu: tahap persiapan dan tahap pelaksanaan. Pada tahap persiapan dilaksanakan melalui penyiapkan perangkat pembelajaran yang akan digunakan pada tahap pelaksanaan pembelajaran. Pada penelitian ini melibatkan 25 orang siswa kelas XII MIA.2 semester 1 Tahun Pelajaran 2019/2020 sebagai subjek penelitian. Untuk mengukur sikap siswa digunakan melalui kuisoner siswa yang terdiri dari 30 pernyataan. Pernyataan tersebut dituangkan pada 4 sub indikator meliputi, (a) sikap terhadap tujuan dan isi mata pelajaran matematika, (b) sikap terhadap pembelajaran matematika, (c) sikap terhadap guru yang mengajar matematika, (d) sikap siswa terhadap kegiatan pembelajaran menggunakan sejarah matematika. Sebelum pembelajaran dimulai lebih dulu siswa disuruh mengisi kuisioner sikap siswa terhadap Mata Pelajaran Matematika. Pelaksanaan pembelajaran selalu diawali dengan menyampaikan kompetensi dasar dan dan indikator hasil belajar sesuai RPP. Guru lalu membacakan sejarah penemuan dan penggunaan statistik dan tokoh-tokoh yang terlibat. Untuk memancing minat siswa guru memotivasi keterlibatan siswa dalam menggali pengetahuan siswa mengenai penggunaan statistika dalam berbagai bidang kehidupan sehari-hari. Siswa kemudian diarahkan untuk menuliskan contoh-contoh penggunaan statistika yang telah didiskusikan. Pembelajaran dilanjutkan dengan membimbing kelompok belajar siswa menyelesaikan permasalahan yang disajikan dalam lembar kerja siswa.

Setelah menyelesaikan lembar kerja, perwakilan setiap kelompok melakukan persentasi atas hasil kerja kelompok. Anggota kelompok yang lain memberikan komentar dan tanggapan. Pembelajaran dilanjutkan dengan memberikan lembar evaluasi pembelajaran untuk mengetahui ketercapaian kompetensi dan tujuan pembelajaran. Siswa mengerjakan evaluasi secara mandiri.

Pembelajaran diakhiri dengan melakukan refleksi mengenai proses pembelajaran yang dilaksanakan. Pada kesempatan ini guru kembali membacakan cerita tokoh matematika yang berperan dalam pengembangan statistika. Ini dilakukan untuk memancing ketertarikan siswa pada pembelajaran matematika. Guru kemudian membimbing siswa untuk menyimpulkan materi pembelajaran dan memberikan tugas untuk mecari tahu sejarah tokoh-tokoh matematika di berbagai media.

Demikian dilaksanakan selanjutnya pada setiap proses pembelajaran baik di awal kegiatan, inti pembelajaran dan kegiatan penutup selalu dikaitkan dengan sejarah matematika dan tokoh matematika yang berkaitan dengan statistik. Setelah pelaksanaan pembelajaran sebanyak 5 kali pertemuan, dilaksanakan ulangan harian untuk mengukur pencapaian prestasi belajar siswa. Pada akhir pembelajaran (pertemuan ke-10) selain ulangan harian kedua, siswa juga diminta mengisi kuisioner sikap siswa pada mata pelajaran matematika.

\section{HASIL DAN PEMBAHASAN}

Setelah pelaksanaan pembelajaran matematika dengan menggunakan sejarah matematika pada kompetensi dasar menentukan dan menganalisis ukuran pemusatan dan penyebaran data yang disajikan dalam bentuk tabel distribusi frekuensi dan histogram di Kelas XII MIA.2 SMAN 1 Kubu Semester I Tahun Pelajaran 
2019/2020 selama 20 JP diperoleh bahwa siswa mengikuti pembelajaran dengan lebih antusias. Pada pembelajaran sebelumnya, siswa kurang tertarik belajar matematika yang dianggap sebagai pelajaran yang susah. Dengan menggunakan sejarah matematika sebagai media pembelajaran, siswa menunjukkan ketertarikan (minat) yang lebih baik pada Mata Pelajaran Matematika. Saat membacakan sejarah matematika yang disiapkan guru maupun dibawa siswa, tampak antusiasme yang tinggi. Sikap siswa pada Mata Pelajaran Matematika juga mengalami peningkatan. Hal itu diketahui dari jawaban siswa pada kuisioner yang diberikan. Sebelum penggunaan sejarah matematika pada pembelajaran sikap siswa kelas XII MIA.2 SMAN 1 Kubu pada rata-rata 48,21 pada kategori Cukup. Dari seluruh siswa sebanyak 25 orang hanya 6 orang pada kategori Baik dan sebanyak 19 orang pada katagori Cukup. Kalau dicermati pada masing-masing indikator, sikap terhadap tujuan dan isi Mata Pelajaran Matematika pada kategori Cukup. Demikian juga pada indikator sikap terhadap pembelajaran matematika, sikap terhadap guru yang mengajar matematika dan sikap siswa terhadap kegiatan pembelajaran menggunakan sejarah matematika juga pada katagori Cukup. Pada akhir pembelajaran dengan penggunaan sejarah matematika semua indikator tersebut mengalami peningkatan. Rata-rata sikap siswa pada indikator sikap terhadap tujuan dan isi mata pelajaran matematika dan sikap terhadap pembelajaran matematika pada katagori Baik. Bahkan pada indikator sikap terhadap guru yang mengajar matematika dan sikap siswa terhadap kegiatan pembelajaran menggunakan sejarah matematika rata-rata sikap siswa pada katagori Sangat Baik. Demikian juga secara rata-rata sikap siswa pada Mata Pelajaran Matematika mengalami peningkatan menjadi rata-rata 74,00 pada kategori Baik. Sebanyak 8 orang siswa menunjukkan sikap katagori sangat baik, sebanyak 13 orang siswa menunjukkan sikap baik dan hanya 4 orang siswa menunjukkan sikap cukup. Rekapitulasi perkembangan sikap matematika siswa kelas XII MIA.2 dari sebelum dan setelah pembelajaran dapat dilihat pada Tabel.1 dan Gambar 1 berikut.

Tabel 1. Peningkatan Sikap Siswa Kelas XII MIA.2 SMAN 1 Kubu Semester 1 Tahun Pelajaran 2019/2020 terhadap Mata Pelajaran Matematika Setelah Pembelajaran dengan Sejarah Matematika

\begin{tabular}{clccc}
\hline No & \multicolumn{1}{c}{ Katagori } & $\begin{array}{c}\text { Sebelum } \\
\text { Pembelajaran }\end{array}$ & $\begin{array}{c}\text { Setelah } \\
\text { Pembelajaran }\end{array}$ & Peningkatan \\
\hline 1 & Sangat Baik & - & 8 & 8 \\
2 & Baik & 6 & 13 & 7 \\
3 & Cukup & 19 & 4 & $(15)$ \\
4 & Kurang & - & - & - \\
5 & Sangat Kurang & - & - & - \\
\hline
\end{tabular}




\section{Peningkatan Sikap Siswa}

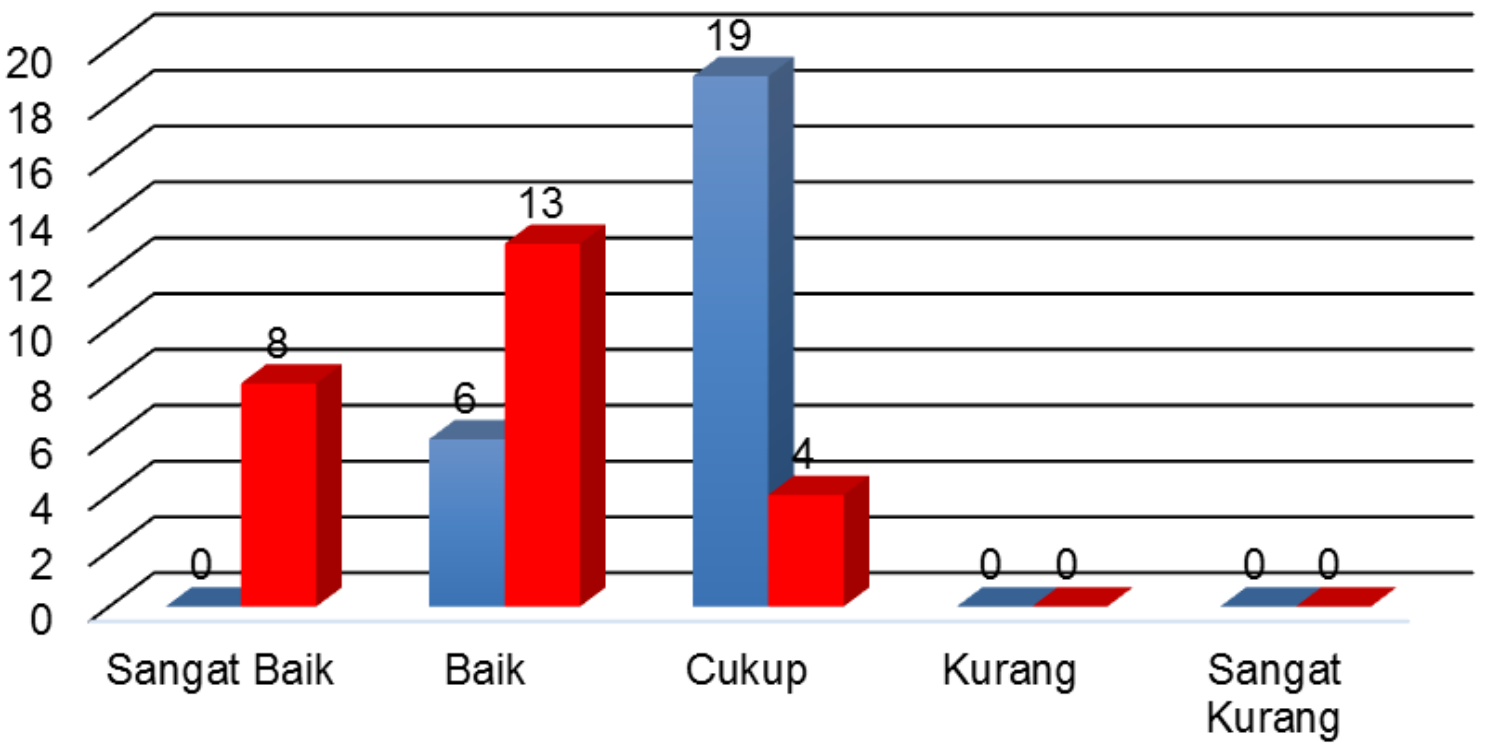

Sebelum Pembelajaran $\quad$ Setelah Pembelajaran

Gambar 1. Peningkatan Sikap Siswa

Sejalan dengan pendapat Michelli (2013) yang menyatakan bahwa sikap siswa terhadap Mata Pelajaran Matematika berpengaruh signifikan pada peningkatan prestasi belajar matematika siswa. Sikap siswa kelas XII MIA.2 SMAN 1 Kubu yang meningkat pada Mata Pelajaran Matematika pada akhirnya meningkatan prestasi belajar matematikanya. Rata-rata nilai ulangan harian siswa meningkat dari ulangan harian
1 pada pertemuan ke- 5 dan ulangan harian 2 pada pertemuan ke-10. Rata-rata nilai ulangan harian 1 siswa 75,48 dengan ketuntasan belajar $92 \%$ meningkat menjadi 78,72 dengan ketuntasan $100 \%$ pada ulangan harian 2. Hal ini berarti penggunaan sejarah matematika pada pembelajaran juga meningkatkan prestasi belajar siswa. Selengkapnya peningkatan hasil ulangan harian siswa dapat diamati pada Tabel 2 dan Gambar 2 berikut.

Tabel 2. Nilai Ulangan Harian Siswa Kelas XII MIA.2 SMAN 1 Kubu Semester 1 Tahun Pelajaran 2019/2020 Setelah Pembelajaran dengan Sejarah Matematika

\begin{tabular}{lcc}
\hline Capaian & UH I & UH II \\
\hline Rata-rata Hasil Belajar & 75,48 & 78,72 \\
Ketuntasan Belajar & $92,00 \%$ & $100 \%$ \\
\hline
\end{tabular}




\section{Peningkatan Prestasi Belajar Matematika}

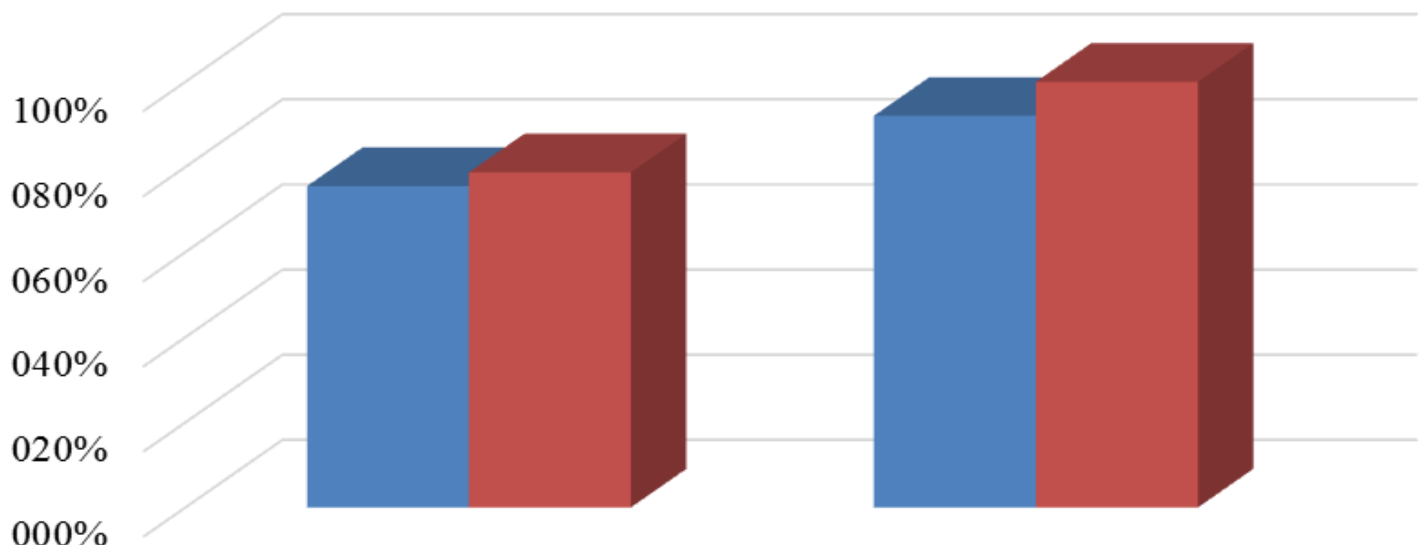

Daya serap

Ketuntasan

UH.1 $\square$ UH.II

Gambar 2. Peningkatan Prestasi Belajar Matematika Siswa

Hasil penelitian ini sejalan dengan hasil temuan Yuli Astuti (2017) menunjukkan bahwa ketertarikan siswa (minat) pada matematika dapat ditumbuhkan dengan mengembangkan persepsi dan sikap positif terhadap mata pelajaran matematika. Guru harus merancang pembelajaran matematika yang mengembangkan sikap positif siswa terhadap mata pelajaran matematika. Lebih lanjut Yuli Astuti memaparkan salah satu pembelajaran yang dapat mengembangkan sikap positif siswa terhadap mata pelajaran matematika adalah penggunaan sejarah matematika.

Penggunaan sejarah matematika dalam pembelajaran merupakan satu upaya untuk meningkatkan sikap siswa Kelas XII MIA.2 SMAN 1 Kubu Semester I Tahun Pelajaran 2019/2020. Sikap merupakan kecenderungan untuk memberikan respon terhadap objek tertentu secara positif maupun negatif (Syah, 2008). Sikap siswa terhadap matematika menurut (Michelli, 2013) memberikan pengaruh yang signifikan pada prestasi belajar siswa.matematika pada pembelajaran juga meningkatkan prestasi belajar siswa. Selengkapnya peningkatan hasil ulangan harian siswa dapat diamati pada Tabel 2 dan Gambar 2 berikut.

Pembelajaran matematika dengan menggunakan sejarah matematika difasilitasi oleh guru sepanjang proses pembelajaran. Guru menggunakan sejarah hidup tokoh matematika yang dibaca siswa pada awal pembelajaran. Pada kegiatan inti pembelajaran, sejarah matematika terkait dengan konsep yang dipelajari siswa diselipkan pada lembar kerja siswa. Selain itu, materi pembelajaran juga dikaitkan dengan sejarah matematika yang sesuai.

Pada kegiatan akhir atau penutup pembelajaran, sejarah matematika menjadi bahan refleksi dan tindak lanjut pembelajaran. Sejarah matematika maupun tokoh matematika juga dipajang di kelas menjadi bahan bacaan bagi siswa.

Berdasarkan refleksi terhadap proses dan hasil pembelajaran matematika menggunakan sejarah matematika di Kelas XII MIA.2 SMA N 1 Kubu Semester 1 Tahun Pelajaran 2019/2020 diperoleh nilai-nilai penting dan kebaruan, yaitu (1) sangat penting bagi guru dan siswa untuk melakukan inovasi dalam pelaksanaan 
pembelajaran matematika. Inovasi yang dilakukan seyogyanya memperhatikan kebutuhan siswa dan potensi yang dimiliki guru dan sekolah pada umumnya. Dengan demikian inovasi yang dilakukan akan memberikan nilai tambah pada proses dan hasil pembelajaran matematika.; (2) penggunaan sejarah matematika dalam pembelajaran matematika memberikan kesadaran bagi siswa akan pentingnya pola pikir matematika dalam kehidupan. Matematika tidak sekadar angka dan rumus yang harus dihapalkan. Matematika adalah latihan bagi pengembangan logika, kreativitas dan kemampuan pemecahan masalah; (3) penggunaan sejarah matematika pada pembelajaran matematika selain meningkatkan sikap positif siswa pada matematika juga dapat mengembangkan karakter siswa. Nilai-nilai sejarah matematika dapat dijadikan acuan untuk mengembangkan karakter siswa. Banyak sikap dan prilaku tokoh matematika yang bisa diteladani siswa. Keuletan, ketekunan, komitmen, disiplin, kerja keras adalah beberapa diantaranya. Karakterkarakter di atas sangat penting untuk dimiliki dan dilaksanakan siswa dalam mengikuti proses pembelajaran maupun menyiapkan diri menjadi bagian masyarakat.

Penerapan sejarah matematika dalam pembelajaran memberikan banyak kontribusi positif, yaitu: (a) memunculkan antusias; (b) sebagai sumber contoh yang menarik dan menyenangkan dalam pembelajaran serta membuat siswa memahami bahwa matematika bukan pelajaran tanpa makna; (c) meningkatkan motivasi dan minat siswa; matematika sebagai capaian manusia sehingga siswa tidak dilemahkan oleh kegagalan, kesalahan, ketidaktentuan, dan kesalahpahaman. Ketiga hal tersebut bisa memberikan kontribusi positif dalam mengubah pandangan dan sikap siswa terhadap matematika yang diawali dengan adanya antusias dalam belajar, peningkatan motivasi dan minat, merasa senang dalam pembelajaran dan percaya bahwa matematika adalah capaian manusia yang dilalui dengan kerja keras.

Selama proses pembelajaran matematika menggunakan sejarah matematika di Kelas XII MIA.2 SMAN 1 Kubu juga ada faktor pendukung dan penghambatnya. Faktor pendukungnya adalah program literasi yang dilaksanakan di sekolah. Pada program ini siswa diwajibkan untuk membaca buku nonpelajaran setiap hari. Buku yang dibaca siswa dapat diarahkan pada buku-buku yang memuat sejarah matematika. Selain itu, keaktifan siswa dalam proses pembelajaran juga merupakan faktor pendukung yang penting. Siswa yang aktif dan terlibat dalam proses pembelajaran ikut menumbuhkan suasana pembelajaran yang kondusif.

Selain faktor yang mendukung ada juga faktor-faktor yang menghambat penggunaan sejarah matematika dalam pembelajaran. Faktor penghambat diantaranya rendahnya minat baca siswa, ketersediaan buku-buku bacaan yang memuat sejarah matematika, pola pikir siswa yang sudah menganggap matematika sebagai mata pelajaran yang sulit dan penuh dengan hapalan angka dan rumus, serta jam pelajaran yang tidak fleksibel. Waktu belajar yang hanya 2 jam pelajaran terkadang terasa sangat kurang untuk membahas materi matematika yang dikaitkan dengan sejarahnya. Untuk mengatasi faktor-faktor pengahambat tersebut guru dan siswa membuat berbagai kesepakatan. Minat baca yang rendah diatasi dengan cara membaca bergilir. Bahan bacaan yang kurang diatasi dengan mengumpulkan berbagai bahan bacaan dari berbagai sumber. Bahan itu kemudian dipajang di kelas dan menjadi sumber belajar di kemudian hari.

\section{PENUTUP}

Berdasarkan analisis data yang telah di paparkan pada bagian-bagian sebelumnya dapat ditemukankan hasil penelitian yang merupakan jawaban terhadap rumusan masalah yang diajukan 


\section{DAFTAR PUSTAKA}

Argaswari, D. P. (2018). Integrasi Sejarah Matematika untuk Meningkatkan Atensi Siswa. Indonesian Journal of Mathematics Education, 1 No.1.

As'ari, A. R. (2018). Pembelajaran Matematika Untuk Pengembangan Karakter Peserta. Seminar Nasional Matematika dan Pendidikan Matematika (pp. 1-10). Purworejo: Pendidikan Matematika Universitas Muhammadiyah Purworejo.

Fauvel, J. (2000). The Role of History of Mathematics Within a University Mathematics Curriculum for the 21st century dalam Teaching and Learning Undergraduate Mathematics (TALUM). Newsletter, No.12.

Furinghetti, F., \& Somaglia, A. (1998). History of mathematics in school across disciplines. Mathematics in School, 2 No.4, 48-51.

Kurnila, V. S., Danto, Y. S., Jundu, R., \& Jelatu, S. (2019). Hubungan Antara Sikap Pada Matematika dan Pemahaman Konsep Matematika Siswa SMP di Kecamatan Langke Rembong. EDU-MAT: Jurnal Pendidikan Matematik, 7, Nomor 1, 41 $-50$.

Parwati, N. N. (2013). Model PPM Matematika Berorientasi Kearifan Lokal Bali Untuk Membentuk Sikap Positif Siswa. Seminar Nasional FMIPA UNDIKSHA III (pp. 112-118). Singaraja: Undiksha Singaraja.

Sumardyono. (2012). Pemanfaatan Sejarah Matematika di Sekolah. Jogjakarta: p4tk. 
Wahyu, K., \& Mahfudy, S. (2016). Sejarah matematika:Alternatif strategi pembelajaran matematika. Beta, Jurnal Tadril Matematika, Vol. 9 No. 1.

Yuli Astuti, Made Sri. (2017). Penggunaan Sejarah Matematika untuk Meningkatkan Motivasi Dan Minat Belajar Siswa Kelas XI PSB SMA Negeri 1 Rendang Karangasem Bali. Laporan PTK. Tidak dipublikasikan. 